\title{
Editorials
}

\section{TICK-BORNE ENCEPHALITIS: ROUNDING OUT THE PICTURE}

\author{
FX Heinz ${ }^{1}$ \\ 1. Institute of Virology, Medical University of Vienna, Vienna, Austria
}

What is now known as tick-borne encephalitis (TBE) was first recognised as a distinct disease entity in 1931 in Europe by $\mathrm{H}$. Schneider and described as 'meningitis serosa epidemica' of unknown etiology [1]. A disease with similar clinical symptoms was reported in the Far East in 1934 and briefly thereafter - in 1937 - the etiologic agent was isolated in Russia and its transmission by ticks could also be demonstrated [2]. In Finland, TBE was initially described as 'Kumlinge disease' in the 1940s [3] and the first European TBE virus was isolated in Czechoslovakia during an epidemic in 1948 [4].

Since those historic days, the scientific development in the area of TBE and flaviviruses in general has been enormous. Today, we are experiencing an explosion of new information, both on the structure and molecular biology of these viruses and the biological principles underlying their natural cycles [5]. It is especially pleasing to see that the purified inactivated vaccine available on the market [6] has an excellent profile of field effectiveness as well as safety, and vaccination therefore proved to be an extremely successful measure for preventing disease [7].

Nevertheless, there are several aspects in the context of TBE that have not yet been satisfactorily dealt with, including the question of different clinical disease pictures induced by the three TBE virus subtypes (European, Siberian, and Far Eastern), the lack of standardisation of case definitions, laboratory diagnosis, reporting and documentation of the disease as well as of endemic areas. The latter issue, of course, relates to possible changes of the distribution of natural TBE virus foci because of climatic changes, and we are only at an early stage of understanding in which way complex biological systems control the maintenance of the virus in nature $[5,8]$.

A critical review of the present surveillance systems for TBE in different European countries - as presented in this issue's article by 0 Donoso Mantke et al [9] - is therefore most welcome, and pinpoints those areas that need to be addressed in further activities of investigation.
References

1. Schneider H. Über epidemische Meningitis serosa. Wien Klin Wschr. 44:350 (1931).

2. Smorodintsev AA. Tick-borne spring-summer encephalitis. Prog Med Virol. 1958;1:210-47.

3. Wahlberg P, Saikku P, Brummer-Korvenkontio M. Tick-borne viral encephalitis in Finland. The clinical features of Kumlinge disease during 1959-1987. J Intern Med. 1989; 225(3):173-7.

4. Gallia F, Rampas J, Hollender J. Laboratori infekce encefalitickym virem. Cas. Lek.Ces. 1949;88:225.

5. Randolph SE, Green RM, Peacy MF, Rogers DJ. Seasonal synchrony: the key to tick-borne encephalitis foci identified by satellite data. Parasitology. 2000 Jul:121 (Pt 1):15-23.

6. Barrett PN, Dorner F, Ehrlich $\mathrm{H}$, et al. Tick-borne encephalitis virus vaccine. In: Plotkin SA, Orenstein WA, eds. Vaccines. 4th ed. Philadelphia: Saunders: 2004:1039-55.

7. Heinz FX, Holzmann H, Essl A, Kundi M. Field effectiveness of vaccination against tick-borne encephalitis. Vaccine. 2007 0ct 23;25(43):7559-67.

8. Nuttall PA, Labuda M. Dynamics of infection in tick-vectors and at the tickhost interface. Adv Virus Res. 2003;60:233-72.

9. Donoso Mantke 0, Schädler R, Niedrig M. A survey on cases of tick-borne encephalitis in European countries. Euro Surveill. 2008;13(17):pii=18848. Available online: http://www.eurosurveillance.org/ViewArticle. aspx?ArticleId $=18848$

This article was published on 24 April 2008.

Citation style for this article: Heinz F. Tick-borne encephalitis: rounding out the picture. Euro Surveill. 2008;13(17):pii=18844. Available online: http://www.eurosurveillance.org/ ViewArticle.aspx?ArticleId $=18844$ 